Proc. Estonian Acad. Sci. Biol. Ecol., 2004, 53, 1, 14-24

\title{
Tropane alkaloid production and riboflavin excretion by Hyoscyamus niger L. hairy root cultures
}

\author{
Rael Vardja ${ }^{a^{*}}$, Katrin Pudersell ${ }^{\mathrm{b}}$, Tõnis Vardja ${ }^{\mathrm{a}}$, Ain Raal ${ }^{\mathrm{b}}$, \\ and Elmar Arak ${ }^{\mathrm{b}}$ \\ a Institute of Experimental Biology, Estonian Agricultural University, Instituudi tee 11, 76902 \\ Harku, Harjumaa, Estonia \\ ${ }^{\mathrm{b}}$ Institute of Pharmacy, University of Tartu, Jakobi 2, 51014 Tartu, Estonia
}

Received 17 November 2003, in revised form 19 December 2003

\begin{abstract}
The production of tropane alkaloids and excretion of riboflavin was comparatively investigated in hairy root clones of Hyoscyamus niger transformed with Agrobacterium rhizogenes strain LBA 9402 and wild-type (WT) root culture of $H$. niger. From six selected hairy root clones, one clone (C-1) was relatively similar to WT roots in morphological features and growth intensity. The other, fast-growing (FG) root clones grew twice better than WT roots and had very variable morphological features. Clone C-1 produced, depending on the medium (MS, B5, Knop-M), 5 to 15 times more scopolamine and 1.5 to 2 times more hyoscyamine than WT roots. Most of the FG root clones produced less tropane alkaloids than WT roots, but there was a strong dependence on the composition of media. The excretion of riboflavin from C-1 clone was somewhat lower than that from the WT roots. The excretion of riboflavin from the FG root clones occurred at a detection level, but increased under iron deficiency of media.
\end{abstract}

Key words: Hyoscyamus niger, wild-type roots, hairy roots, tropane alkaloids, riboflavin.

Hyoscyamus niger L. (Solanaceae) has been regarded a rich source of tropane alkaloids such as hyoscyamine and scopolamine. Wild-type (WT) root culture of $H$. niger has been studied for the production of tropane alkaloids in vitro (Hasimoto et al., 1986; Jung et al., 2001; Pudersell et al., 2003). Most of the reported WT roots, also other Solanaceae WT roots, require auxins for vigorous growth; however, $H$. niger WT root cultures have been shown not to be typical. They proliferate vigorously in liquid medium without auxins and produce a large amount of alkaloids (Shimomura et al., 1991; Robins \& Dräger, 1995; Pudersell et al., 2003).

\footnotetext{
*Corresponding author, rael19@hot.ee
} 
Infection of plant cells by Agrobacterium rhizogenes usually results in hairy root formation at the sites of infection. The integration of the transferred DNA of Ri plasmids causes metabolic changes in auxin and cytokinin syntheses, which result in morphogenetic alterations (plagiotrophic growth, high branching, etc.) of the formed hairy roots (Zambryski et al., 1989). The A. rhizogenes strain used for the transformation of these root clones (Vanhala et al., 1995) has a significant influence on the phenotype of the hairy root clone, on its growth rate, and tropane alkaloid production.

A. rhizogenes-mediated hairy root cultures are fast growing (Hamill et al., 1986; Jung \& Tepfer, 1987) and genetically stable (Aird et al., 1988), and the Ritransformed state is maintained during long periods of culture (João \& Brown, 1994). Hairy roots produce secondary metabolites even in higher amounts than the parent plants (Kamada et al., 1986; Christen et al., 1989; Oksman-Caldentey et al., 1989).

The results of our preceding work showed that the WT root culture of $H$. niger produces increased levels of the alkaloid scopolamine of higher economic value and decreased levels of hyoscyamine compared with the field culture of H. niger (Pudersell et al., 2003). Pudersell and co-workers (Pudersell et al., 2004) established that excised WT roots of $H$. niger excrete a large amount of riboflavin into the growth medium.

The aim of this study was to investigate the capability of clones of hairy roots of $H$. niger to produce tropane alkaloids and the excretion of riboflavine into the culture medium.

\section{MATERIAL AND METHODS}

\section{Bacterium strain}

Agropine strain A.rhizogenes LBA 9402 (gift from Norwich laboratory, England) carrying the kanamycin resistance (NPT II) and $\beta$-glucuronidase (gus) genes was used for transformation. A. rhizogenes was grown in $\mathrm{YMB}\left(0.5 \mathrm{~g} \mathrm{~L}^{-1}\right.$ $\mathrm{K}_{2} \mathrm{HPO}_{4}, 0.2 \mathrm{~g} \mathrm{~L}^{-1} \mathrm{MgSO}_{4}, 0.1 \mathrm{~g} \mathrm{~L}^{-1} \mathrm{NaCl}, 10 \mathrm{~g} \mathrm{~L}^{-1}$ mannitol, $0.4 \mathrm{~g} \mathrm{~L}^{-1}$ yeast extract, $\mathrm{pH}$ 7.0) medium. The bacterium was agitated to intensive growth by subculturing in $\mathrm{YMB}$ medium at $25^{\circ} \mathrm{C}$ in the dark on a rotatory shaker $(90 \mathrm{rpm})$ for $24 \mathrm{~h}$ before its use in transformation.

\section{Transformation procedure}

Leaves from sterile plants were cut into pieces of ca $0.5 \times 0.5 \mathrm{~cm}$ and co-cultivated with a 24-h-old A. rhizogenes suspension culture diluted four times in $1 / 2 \mathrm{MS}$ (Murashige \& Skoog, 1962) liquid medium (ca $10^{5}$ cells $\mathrm{mL}^{-1}$ ) for $30 \mathrm{~min}$. After that the leaf segments were dried with sterile filter paper, placed onto the MS solid medium ( $0.7 \%$ agar) containing $500 \mathrm{mg} \mathrm{L}^{-1}$ cefotaxime 
(Claforan ${ }^{\circledR}$, Rousell, France) and $100 \mathrm{mg} \mathrm{L}^{-1}$ kanamycin (to select kanamycinresistant primary hairy roots), and incubated in illuminated phytotrone (light intensity $20 \mu \mathrm{mol} \mathrm{m}^{-2} \mathrm{~s}^{-1}$ ) at $22 \pm 2{ }^{\circ} \mathrm{C}$. About a fortnight after the inoculation the formation of 2-4 roots on the segments of leaves was observed.

One root was excised from each of the leaf pieces. These roots were called hairy root clones. Roots were transferred to $300 \mathrm{~mL}$ conical flasks containing $50 \mathrm{~mL}$ MS liquid medium supplemented with $2 \%$ sucrose and $200 \mathrm{mg} \mathrm{L}^{-1}$ cephotaxime for purification of roots from bacteria. The root cultures were subcultured 6 times after every 3 weeks. The root cultures were purified and multiplied on a shaker at $90 \mathrm{rpm}$ in a dark phytotron at $25 \pm 2{ }^{\circ} \mathrm{C}$. After the third subculture in the purification medium, 6 well-growing hairy root clones that were morphologically different from the WT root clone were selected from 30 hairy root clones.

\section{Growing conditions of root culture}

Root segments of $3 \mathrm{~cm}$ were transferred into the fresh medium after every 28 days. For the multiplication of roots the MS complete medium, B5 medium (Gamborg et al., 1968), and Knop (Knop, 1865) macronutrients medium supplemented with MS miconutrients and organics (Knop-M) plus 2\% sucrose were used. The growth of the roots was followed by transferring $100 \mathrm{mg}$ of fresh roots or four $3-\mathrm{cm}$ root tips (depending on the experiment) to $50 \mathrm{~mL}$ of liquid media in $300 \mathrm{~mL}$ conical flasks.

\section{$\beta$-glucuronidase (GUS)-assay}

The presence of GUS activity in the root clones was detected histochemically (Jefferson, 1987) using 5-bromo-4-chloro-3-indolyl- $\beta$-D-glucouronide (x-gluc) as substrate.

\section{Determination of the content of tropane alkaloids}

For HPLC determination of tropane alkaloids in the root material of $\mathrm{H}$. niger alkaloids were extracted with ether according to a previously elaborated methodology, and the content of both tropane alkaloids, hyoscyamine and scopolamine, was determined (Pudersell et al., 2003). The authentic preparations of the respective pure alkaloids (Sigma) were used as reference substances.

\section{Determination of riboflavin}

The concentration of riboflavin was determined fluorimetrically using a fluorimeter Analiz (Geologorazvedka, St. Petersburg, Russia). The maximum exitation wavelength was $436 \mathrm{~nm}$ and the emitted light was passed through a $500 \mathrm{~nm}$ cut- 
off filter. The riboflavine content in the medium was calculated using comparison with standard curves established with authentic riboflavin (Chemapol, Prague, Czechoslovakia).

The data were subjected to analysis of variance. The means were compared using Duncan's multiple range test (DMRT).

\section{RESULTS AND DISCUSSION}

Clones of hairy roots selected for the present study had various morphological features. Clone 1 was morphologically similar to WT roots. There was no branching characteristic of typical hairy roots, but roots were thickened compared with the WT root culture. Roots of clone 6 were very thick, and lateral roots were very short. Other hairy root clones were highly branched semblance, with shorter (C-2) or longer (C-9) lateral roots and various density of lateral roots (Fig. 1).
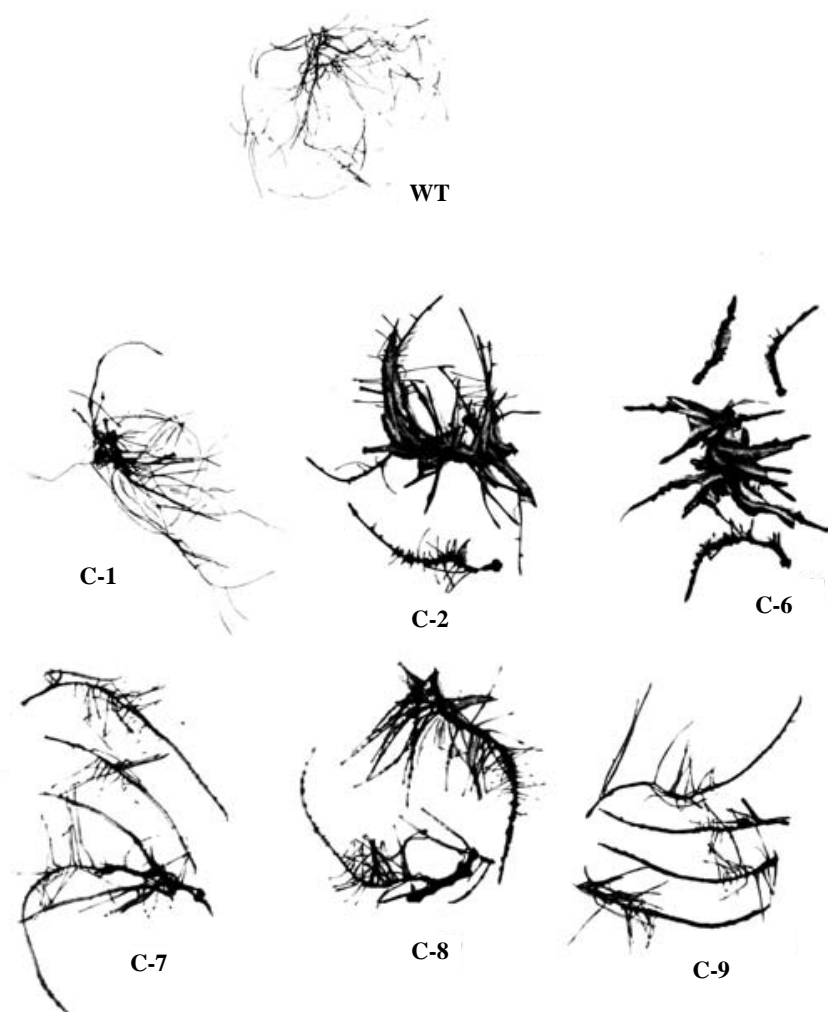

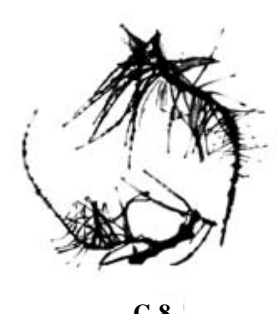

C-8

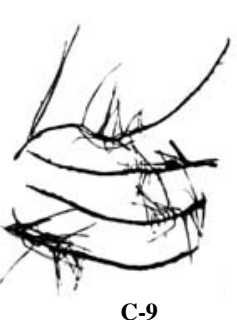

C-9

Fig. 1. Part of a bundle (contact copies) of wild-type (WT) and hairy root clones (C). 
The activity of GUS was detected in most hairy root clones except clone 7 (Table 1). As hairy root clones were selected by kanamycin resistance, all they obviously contain the NPT II gene. This is not suprising as hairy root clones have often shown the absence of one or more genetic markers (Vries-Uijtewaal et al., 1989; Dobigny et al., 1995).

As root clones growing vigorously in the liquid medium without auxins were selected for the experiments, we cannot assert that our data are valid for the whole spectrum of the potential hairy roots of $H$. niger. The growth of some Ritransgenic root clones may be even less than that of WT roots (Dobigny et al., 1995). In our selection the growth of most fast-growing (FG) hairy root clones (C-2, C-6, C-7, C-8, C-9) exceeded that of WT roots more than twice. The excretion of riboflavin into the B5 medium from FG roots was very low, remaining practically at the detection level. The growth of hairy root clone 1 was slightly better than that of WT roots, but its capacity of excreting riboflavin into the medium was lower (Table 1).

The content of hyoscyamine in FG roots was up to six times less than in WT roots. In hairy root clone 1 the content of hyoscyamine was twice less than in WT roots (Table 1 ).

The content of scopolamine in hairy root clones varied greatly. In hairy root clone 8 the content of scopolamine was five times less than in the WT roots, in clone 6 (morphologically most different from the WT roots) the content of scopolamine was slightly (1.4 times) higher than in the WT roots, but in clone 1 the content of scopolamine was even 15 times higher than in the WT roots (Table 1).

Table 1. Growth, excretion of riboflavin, and the content of tropane alkaloids in the wild-type and hairy root cultures of Hyoscyamus niger grown in B5 medium (28-day culture; inoculum $100 \pm 10 \mathrm{mg}$ fresh roots $)^{1}$

\begin{tabular}{c|c|c|c|c|c}
\hline Root clone & $\begin{array}{c}\text { GUS } \\
\text { activity }\end{array}$ & $\begin{array}{c}\text { Growth, } \\
\text { dry weight }_{\mathrm{mg} \mathrm{flask}^{-1}}\end{array}$ & $\begin{array}{c}\text { Riboflavin content } \\
\text { in the medium, } \\
\mathrm{mg} \mathrm{L}^{-1}\end{array}$ & $\begin{array}{c}\text { Hyoscyamine } \\
\text { content } \\
\text { in the roots, } \\
\mathrm{mg} \mathrm{g}^{-1}\end{array}$ & $\begin{array}{c}\text { Scopolamine } \\
\text { content } \\
\text { in the roots, } \\
\mathrm{mg} \mathrm{g}^{-1}\end{array}$ \\
\hline $\begin{array}{l}\text { Wild type } \\
\text { Hairy root }\end{array}$ & - & $147 \pm 12^{\mathrm{d}}$ & $3.12 \pm 0.18^{\mathrm{a}}$ & $2.12 \pm 0.22^{\mathrm{a}}$ & $5.86 \pm 0.24^{\mathrm{c}}$ \\
C-1 & + & $189 \pm 18^{\mathrm{c}}$ & $2.18 \pm 0.11^{\mathrm{b}}$ & $1.14 \pm 0.02^{\mathrm{b}}$ & $88.87 \pm 1.77^{\mathrm{d}}$ \\
C-2 & + & $383 \pm 23^{\mathrm{a}}$ & $0.07 \pm 0.01^{\mathrm{c}}$ & $\mathrm{ND}$ & $\mathrm{ND}$ \\
C-6 & + & $341 \pm 19^{\mathrm{ab}}$ & $0.09 \pm 0.01^{\mathrm{c}}$ & $0.351 \pm 0.007^{\mathrm{c}}$ & $8.55 \pm 0.17^{\mathrm{b}}$ \\
C-7 & - & $346 \pm 28^{\mathrm{ab}}$ & $0.06 \pm 0.02^{\mathrm{c}}$ & $0.373 \pm 0.007^{\mathrm{c}}$ & $2.03 \pm 0.41^{\mathrm{d}}$ \\
C-8 & + & $366 \pm 20^{\mathrm{ab}}$ & $0.08 \pm 0.01^{\mathrm{c}}$ & $0.285 \pm 0.006^{\mathrm{d}}$ & $1.04 \pm 0.21^{\mathrm{d}}$ \\
C-9 & + & $329 \pm 16^{\mathrm{b}}$ & $0.02 \pm 0.02^{\mathrm{d}}$ & $\mathrm{ND}$ & $\mathrm{ND}$
\end{tabular}

ND - not detected.

1 Values are means of 10 replicates \pm standard error; means within columns having different letters are significantly different according to DMRT at $P>0.05$. 
Excised WT roots of most tropane alkaloid-synthesising plants (Hyoscyamus muticus, H. albus, Atropa belladonna, Datura sp. etc.) do not grow well in media without exogenous growth regulators. Therefore WT root cultures grown in media with auxins were used for the comparative examination of alkaloid production. Zehra et al. (1998) found that the hairy root cultures of $H$. albus produce less scopolamine than WT roots (grown in a medium containing $0.5 \mathrm{mg} \mathrm{L}^{-1} \mathrm{IBA}$ ). Our experiments show that in the case of hairy roots of $H$. niger a hairy root clone (C-1) may produce large amounts of scopolamine compared with WT roots.

The maintenance of $H$. niger root cultures in media with various formulations (MS, Knop-M, B5) demonstrated that the morphology of roots remained unchanged (data not given). The composition of the media had relatively little effect on the growth of all types of roots. In the $\mathrm{B} 5$ medium (ratio $\mathrm{NH}_{4}{ }^{+} / \mathrm{NO}_{3}{ }^{-}=2 / 25$ ) the growth of roots was slightly more than in the MS medium (20/39), and in the Knop-M medium (0/10) the growth of roots was slightly lower than in the MS medium (Table 2). Our results are consistent with those of other authors, reporting that ammonia salts or a high ratio of $\mathrm{NH}_{4}{ }^{+} / \mathrm{NO}_{3}{ }^{-}$in media inhibit the growth of roots (Oksman-Caldentey et al., 1994; Yamamoto \& Kamura, 1997). Ammonium is very diffusive and it easily accumulates into the tissues, becoming very toxic if not immediately metabolized (Richter, 1993). Excessive ammonium has direct or

Table 2. Growth, excretion of riboflavin, and tropane alkaloid production in wild-type and hairy root clones of Hyoscyamus niger grown in different media (28-day culture; inoculum $100 \pm 10 \mathrm{mg}$ fresh roots $)^{1}$

\begin{tabular}{|c|c|c|c|c|c|}
\hline \multirow[t]{2}{*}{$\begin{array}{l}\text { Root clone } \\
\text { and medium }\end{array}$} & \multirow[t]{2}{*}{$\begin{array}{l}\text { Dry weight, } \\
\text { mg flask }^{-1}\end{array}$} & \multicolumn{2}{|c|}{ Riboflavin in the medium } & \multicolumn{2}{|c|}{$\begin{array}{l}\text { Alkaloid content in the roots, } \\
\mathrm{mg} \mathrm{g}^{-1} \text { of root dry weight }\end{array}$} \\
\hline & & $\begin{array}{c}\mathrm{mg} \mathrm{L}^{-1} \\
\text { of the medium }\end{array}$ & $\begin{array}{c}\mathrm{mg} \mathrm{g}^{-1} \\
\text { of root dry weight }\end{array}$ & Hyoscyamine & Scopolamine \\
\hline \multicolumn{6}{|l|}{ Wild type } \\
\hline MS & $143 \pm 13^{\mathrm{e}}$ & $3.84 \pm 0.18^{\mathrm{a}}$ & $1.34 \pm 0.02^{\mathrm{a}}$ & $2.32 \pm 0.22^{x}$ & $5.87 \pm 0.42^{\mathrm{d}}$ \\
\hline Knop-M & $132 \pm 8^{f}$ & $2.95 \pm 0.16^{\mathrm{b}}$ & $1.12 \pm 0.03^{\mathrm{b}}$ & $2.31 \pm 0.19^{c}$ & $0.93 \pm 0.08^{f}$ \\
\hline B5 & $177 \pm 9^{c}$ & $3.01 \pm 0.08^{\mathrm{b}}$ & $0.85 \pm 0.02^{\mathrm{c}}$ & ND & ND \\
\hline \multicolumn{6}{|l|}{ Clone 1} \\
\hline MS & $160 \pm 7^{\mathrm{d}}$ & $2.43 \pm 0.09^{c}$ & $0.84 \pm 0.01^{\mathrm{c}}$ & $2.18 \pm 0.11^{\mathrm{c}}$ & $7.89 \pm 0.39^{c}$ \\
\hline Knop-M & $145 \pm 10^{\mathrm{e}}$ & $1.86 \pm 0.10^{\mathrm{e}}$ & $0.64 \pm 0.02^{\mathrm{d}}$ & $4.47 \pm 0.22^{\mathrm{a}}$ & $65.60 \pm 3.28^{\mathrm{a}}$ \\
\hline B5 & $188 \pm 12^{\mathrm{c}}$ & $2.49 \pm 0.07^{\mathrm{c}}$ & $0.66 \pm 0.02^{\mathrm{d}}$ & $3.75 \pm 0.19^{\mathrm{b}}$ & $28.48 \pm 1.42^{\mathrm{b}}$ \\
\hline \multicolumn{6}{|l|}{ Clone 8} \\
\hline MS & $298 \pm 16^{\mathrm{b}}$ & $0.07 \pm 0.01^{\mathrm{f}}$ & $0.012 \pm 0.002^{\mathrm{e}}$ & - & $4.73 \pm 0.24^{\mathrm{e}}$ \\
\hline Knop-M & $285 \pm 19^{b}$ & $0.08 \pm 0.01^{\mathrm{f}}$ & $0.014 \pm 0.001^{\mathrm{e}}$ & $0.47 \pm 0.02^{\mathrm{e}}$ & $6.12 \pm 0.31^{\mathrm{d}}$ \\
\hline B5 & $360 \pm 14^{\mathrm{a}}$ & $0.06 \pm 0.02^{\mathrm{f}}$ & $0.008 \pm 0.003^{\mathrm{e}}$ & $1.16 \pm 0.06^{\mathrm{d}}$ & $3.92 \pm 0.21^{\mathrm{e}}$ \\
\hline
\end{tabular}


indirect repressive effect on nitrate accumulation (Crawford, 1995). However, the effect of the ratio $\mathrm{NH}_{4}{ }^{+} / \mathrm{NO}_{3}{ }^{-}$varies from one clone to another. In the case of a low concentration of ammonia salts or a low ratio of $\mathrm{NH}_{4}{ }^{+} / \mathrm{NO}_{3}{ }^{-}$(B5 medium) the growth of roots increases in many plants (Oksman-Caldentey et al., 1994; Bensaddek et al., 2001). The same happened in our experiment with $H$. niger roots.

The effect of the composition of the media on the excretion of riboflavin into the media was relatively low, too. The excretion of riboflavin into the Knop-M medium was somewhat reduced (Table 2).

Differently from root growth, the content of tropane alkaloids was quite significantly affected in all types of $H$. niger roots by the composition of the medium. The production of hyoscyamine in the WT root cultures grown in the MS and Knop-M media was almost the same. However, in hairy root clone 1 the production of hyoscyamine in the Knop-M medium was more than twice that in the B5 medium and 1.5 times higher than in the MS medium.

In clone 8 the content of hyoscyamine remained below the detection limit, and in the B5 medium it was more than twice that in the Knop-M medium. The content of scopolamine was the highest in clone 8 hairy roots grown in the Knop$\mathrm{M}$ medium and the lowest in the B5 medium (Table 2).

On the basis of data by other authors (Bensaddek et al., 2001) the $\mathrm{NH}_{4}{ }^{+} / \mathrm{NO}_{3}{ }^{-}$ ratio has a significant effect on the production of tropane alkaloids by hairy roots. The reduction in the nitrate concentration (increase in the $\mathrm{NH}_{4}{ }^{+} / \mathrm{NO}_{3}{ }^{-}$ratio) in the MS medium leads to an increased alkaloid production in the hairy roots of A. belladonna. The scopolamine/hyoscyamine ratio is increased when the nitrate and ammonium concentrations are raised. In H. muticus hairy root cultures the effect of the $\mathrm{NH}_{4}{ }^{+} / \mathrm{NO}_{3}{ }^{-}$ratio on the hyoscyamine content follows the same pattern as on growth. The growth and tropane alkaloid production in $\mathrm{H}$. muticus hairy root clones do not depend on the total amount of nitrogen in the medium. When the nitrogen concentration remains between 10 and $75 \mathrm{mM}$, the growth and hyoscyamine production are almost at the same level (Oksman-Caldentey et al., 1994). In Datura quercifolia hairy roots the growth and tropane alkaloid content are depressed by highly concentrated media. The dilution of the culture media and the reduction of nitrogen concentrations enhance growth and alkaloid content in hairy root cultures (Parr et al., 1990; Dupraz et al., 1993).

In our experiment both the reduction of the nitrogen concentration in the media and more diluted media (Knop-M $<$ B5 $<$ MS) exerted varying effects on tropane alkaloid production in the root cultures of $H$. niger. In the more diluted media the scopolamine content decreased in the WT roots and increased in the hairy root clone. In clone 8 the yield of total tropane alkaloids increased, but in the B5 medium, compared with the MS medium, the content of scopolamine decreased.

The excretion of riboflavin from the FG hairy root clones into the media containing $100 \mu \mathrm{M}$ of iron was very low, practically at the detection level. For the estimation of riboflavin excretion from FG hairy roots we used the fact that 
the excretion of riboflavin increases under iron deficiency in the media from intact plant roots (Welkie, 1993) as well as WT excised roots of H. niger (Pudersell et al., 2004). Our results (Tables 3,4) showed increased riboflavin excretion from both WT roots and hairy root clone 8 under iron deficiency or in iron-lacking media. The greatest increase in the riboflavin (32 times, expressed on root dry weight basis) excretion was observed into the MS medium lacking iron in the case of hairy root clone 8 . The riboflavin excretion into the same medium from the WT roots increased only 4.4 times. The riboflavin excretion

Table 3. Influence of Fe(III)EDTA concentration of nutrient solutions on the content of excreted riboflavin in wild-type root culture of Hyoscyamus niger (4 root tips; 28-day culture) ${ }^{1}$

\begin{tabular}{l|c|c|c}
\hline \multirow{2}{*}{ Medium } & $\begin{array}{c}\text { Dry weight } \\
\text { of roots, } \\
\text { mg per flask }\end{array}$ & \multicolumn{2}{c}{ Riboflavin content in the medium } \\
\cline { 3 - 4 } & $\begin{array}{c}\text { mg per L } \\
\text { of the medium }\end{array}$ & $\begin{array}{c}\text { mg per g } \\
\text { of root dry weight }\end{array}$ \\
\hline MS & & & \\
Standard & $18 \pm 2^{\mathrm{c}}$ & $0.59 \pm 0.09^{\mathrm{e}}$ & $1.63 \pm 0.19^{\mathrm{e}}$ \\
$1 / 2 \mathrm{Fe}$ & $28 \pm 4^{\mathrm{a}}$ & $1.72 \pm 0.13^{\mathrm{d}}$ & $3.07 \pm 0.22^{\mathrm{d}}$ \\
0 Fe & $25 \pm 2^{\mathrm{a}}$ & $3.83 \pm 0.12^{\mathrm{a}}$ & $7.20 \pm 0.18^{\mathrm{b}}$ \\
Knop-M & & & \\
Standard & $14 \pm 2^{\mathrm{d}}$ & $1.26 \pm 0.07^{\mathrm{c}}$ & $4.51 \pm 0.24^{\mathrm{c}}$ \\
$1 / 2 \mathrm{Fe}$ & $23 \pm 2^{\mathrm{b}}$ & $2.3 \pm 0.09^{\mathrm{b}}$ & $4.90 \pm 0.28^{\mathrm{c}}$ \\
$0 \mathrm{Fe}$ & $12 \pm 3^{\mathrm{d}}$ & $2.2 \pm 0.14^{\mathrm{b}}$ & $9.16 \pm 0.32^{\mathrm{a}}$
\end{tabular}

1 Values are means of 10 replicates \pm standard error; means within columns having different letters are significantly different according to DMRT at $P>0.05$.

Table 4. Influence of Fe(III)EDTA concentration of nutrient solutions on the content of excreted riboflavin in fast-growing hairy root clone C-8 of Hyoscyamus niger (4 root tips; 28-day culture) ${ }^{1}$

\begin{tabular}{l|c|c|c}
\hline \multirow{2}{*}{ Medium } & \multirow{2}{*}{$\begin{array}{c}\text { Dry weight } \\
\text { of roots, } \\
\text { mg per flask }\end{array}$} & \multicolumn{2}{|c}{ Riboflavin content in the medium } \\
\cline { 3 - 4 } & & $\begin{array}{c}\text { mg per L } \\
\text { of the medium }\end{array}$ & $\begin{array}{c}\text { mg per g } \\
\text { of root dry weight }\end{array}$ \\
\hline MS & $206 \pm 20^{\mathrm{a}}$ & $0.12 \pm 0.03^{\mathrm{e}}$ & $0.029 \pm 0.008^{\mathrm{e}}$ \\
$\quad$ Standard & $213 \pm 16^{\mathrm{a}}$ & $0.17 \pm 0.02^{\mathrm{e}}$ & $0.039 \pm 0.007^{\mathrm{e}}$ \\
$1 / 2 \mathrm{Fe}$ & $116 \pm 11^{\mathrm{d}}$ & $2.09 \pm 0.12^{\mathrm{a}}$ & $0.950 \pm 0.034^{\mathrm{a}}$ \\
$0 \mathrm{Fe}$ & & & \\
Knop-M & $160 \pm 18^{\mathrm{b}}$ & $0.33 \pm 0.04^{\mathrm{c}}$ & $0.071 \pm 0.021^{\mathrm{d}}$ \\
$\mathrm{Standard}$ & $135 \pm 18^{\mathrm{c}}$ & $0.54 \pm 0.04^{\mathrm{b}}$ & $0.201 \pm 0.014^{\mathrm{c}}$ \\
$1 / 2 \mathrm{Fe}$ & $33 \pm 11^{\mathrm{e}}$ & $0.22 \pm 0.02^{\mathrm{d}}$ & $0.333 \pm 0.039^{\mathrm{b}}$ \\
$0 \mathrm{Fe}$ & &
\end{tabular}

1 Values are means of 10 replicates \pm standard error; means within columns having different letters are significantly different according to DMRT at $P>0.05$. 
into the iron-deficient Knop-M media was lower than into the iron-deficient MS media. The increase (expressed on root dry weight basis) in the riboflavin excretion did not depend on the growth of roots in iron-deficient media, as in almost all media the riboflavin content increased if expressed per litre of the medium.

The roots of some plant cultivars that use iron efficiently (Fe-efficient plants) excrete more riboflavin than Fe-inefficient cultivars (Welkie, 1993, 1996). The significance of the excretion of riboflavin in large amounts from iron-stressed plants or excised roots is still unclear. The roots absorbed only reduced $\mathrm{Fe}^{2+}$. In soil as well as in media $\mathrm{Fe}^{3+}$ prevails. Thus the roots have to reduce $\mathrm{Fe}^{3+}$ to $\mathrm{Fe}^{2+}$. A specific form of riboflavin-flavin mononucleotide functions in the iron reducing process. The fact that the Fe-efficient plants excrete riboflavin into the culture media was interpreted as the ability of certain plants to increase their Fe utilization under Fe-deficiency stress by, in part, synthesizing more riboflavin that can contribute to Fe reduction at the epidermal plasmalemma (Welkie, 1996). Our results concerning the decrease in the riboflavin excretion from FG hairy roots of $H$. niger can be interpreted as the Fe-inefficiency of FG hairy roots.

\section{CONCLUSIONS}

Six hairy root clones of Hyoscyamus niger transformed with Agrobacterium rhizogenes strain LBA 9402 exhibited different patterns of growth, morphology, tropane alkaloid production, and riboflavin excretion into the medium. Clone 1, which was relatively similar to the WT root culture in morphology and growth intensity, produced more (up to 8 times) tropane alkaloids, especially scopolamine (up to 15 times) than the WT roots. The FG clone 6, which was morphologically most different from WT roots, produced 1.5 times more scopolamine than the WT roots. Other FG clones produced less alkaloids than the WT roots.

The excretion of riboflavin into the media was the highest in the case of WT roots. The excretion of riboflavin from the FG hairy roots was very low on the media of high iron level. In the absence of iron the riboflavin excretion rose up to 33 times, but the excretion level of riboflavin from the FG roots into the irondeficient media remained up to 10 times less than that from the WT roots into the media containing $100 \mu \mathrm{M} \mathrm{Fe}$.

The production of alkaloids by both WT roots and hairy root clones depended on the composition of the media. However, these dependences were not regular. The WT roots produced six times less scopolamine in the Knop-M medium compared with the MS medium. On the contrary, clone 1 produced 8 times more scopolamine in the Knop-M medium than in the MS medium. Therefore, each clone of roots needs an individual approach depending on the product we want to get with the assistance of that root culture. 


\section{REFERENCES}

Aird, E. L. H., Hamill, J. H. \& Rhodes, M. J. C. 1988. Cytogenetic analysis of hairy root cultures from a number of plant species transformed by Agrobacterium rhizogenes. Plant Cell Tiss. Organ Cult., 15, 47-57.

Bensaddek, L., Gillet, F., Saucedo, J. E. N. \& Filiniaux, M.-A. 2001. The effect of nitrate and ammonium concentrations on growth and alkaloid accumulation of Atropa belladonna hairy roots. J. Biotech., 85, 35-40.

Christen, P., Roberts, M. F., Phillipson, J. D. \& Evans, W. C. 1989. High-yield production of tropane alkaloids by hairy-root cultures of a Datura candida hybrid. Plant Cell Rep., 8, 75-77.

Crawford, N. M. 1995. Nitrate: nutrient and signal for plant growth. Plant Cell, 7, 859-868.

Dobigny, A., Ambroise, A., Haicour, R., David, C., Rossignol, L. \& Sihachakr, D. 1995. Transformation of potato using mannopine and cucumopine strains of Agrobacterium rhizogenes. Plant Cell Tiss. Organ Cult., 40, 225-230.

Dupraz, J. M., Christen, P. \& Kapetanidis, I. 1993. Tropane alkaloids in transformed roots of Datura quercifolia. Planta Med., 60, 158-162.

Gamborg, O. L., Miller, R. A. \& Ojima, K. 1968. Nutrient requirements of suspension cultures of soybean root cells. Exp. Cell Res., 50, 151-158.

Hamill, J. D., Parr, A. J., Robins, R. J. \& Rhodes, M. J. C. 1986. Secondary product formation by cultures of Beta vulgaris and Nicotiana rustica transformed with Agrobacterium rhizogenes. Plant Cell Rep., 5, 111-114.

Hasimoto, T., Yukimune, Y. \& Yamada, Y. 1986. Tropane alkaloid production in Hyoscyamus root cultures. J. Plant Physiol., 134, 61-75.

Jefferson, R. A. 1987. Assaying chimaeric genes in plants: the GUS gene fusion system. Plant Mol. Biol. Rep., 5, 387-405.

João, K. H. L. \& Brown, T. A. 1994. Long-term stability of root cultures of tomato transformed with Agrobacterium rhizogenes R1601. J. Exp. Biol., 45, 641-647.

Jung, D. W., Sung, C. K., Touno, K., Yoshimatsu, K. \& Shimomura, K. 2001. Cryopreservation of Hyoscyamus niger adventitious roots by vitrification. J. Plant Physiol., 159, 801-805.

Jung, G. \& Tepfer, D. 1987. Use of genetic transformations by the Ri-T-DNA of Agrobacterium rhizogenes to stimulate biomass and tropane alkaloid production in Atropa belladonna and Callystegia sepium root growth in-vitro. Plant Sci., 50, 145-151.

Kamada, H., Okamura, N., Satake, M., Harada, H. \& Shimomura, K. 1986. Alkaloid production by hairy root cultures in Atropa belladonna. Plant Cell Rep., 5, 239-242.

Knop, W. 1865. Quantitative Untersuchungen über die Ernahrungsprozesse der Pflanzen. Landwirtsch. Vers. Stn., 7, 93-107.

Murashige, T. \& Skoog, F. A. 1962. A revised medium for rapid growth and bio-assays with tobacco tissue culture. Physiol. Plant., 15, 473-497.

Oksman-Caldentey, K. M., Parkkinen, O., Jaki, E. \& Hiltunen, R. 1989. Increased production of tropane alkaloids by conventional and transformed root cultures of Hyoscyamus muticus. Planta Med., 55, 107.

Oksman-Caldentey, K. M., Sevón, N., Vanhala, L. \& Hiltunen, R. 1994. Effect of nitrogen and sucrose on the primary and secondary metabolism of transformed root cultures of Hyoscyamus muticus. Plant Cell Tiss. Organ Cult., 38, 263-272.

Parr, A. J., Payne, J., Eagles, J., Chapman, B. T., Robins, R. J. \& Rhodes, J. C. 1990. Variation in tropane alkaloid accumulation within the Solanaceae and strategies for its exploitation. Phytochemistry, 29, 2545-2550.

Pudersell, K., Vardja, R., Vardja, T., Raal, A. \& Arak, E. 2003. Plant nutritional elements and tropane alkaloid production in the roots of henbane (Hyoscyamus niger). Pharm. Biol., 41, 226-230.

Pudersell, K., Vardja, T., Vardja, R. \& Tohver, A. 2004. Riboflavin excretion from the excised roots of Hyoscyamus niger. Pharm. Biol. (in press). 
Richter, G. 1993. Metabolisme des végétaux; physiologie et biochimie. Presses Polytechniques et Universitaires Romandes, Lausanne.

Robins, R. J. \& Dräger, B. 1995. Tropane alkaloid synthesis in root cultures. In Plant Tissue Culture Manual, pp. 1-17. Kluwer Academic Publishers, Netherlands, GI.

Shimomura, K., Sauerwein, M. \& Ishimaru, K. 1991. Tropane alkaloids in the adventitious and hairy root cultures of solanaceous plants. Phytochemistry, 30, 2275-2278.

Vanhala, L., Hiltunen, R. \& Oksman-Caldentey, K. M. 1995. Influence of different Agrobacterium strains on hairy root formation of Hyoscyamus muticus. Plant Cell Rep., 14, 238-240.

Vries-Uijtewaal de, E., Glissen, L. J. W., Flipse, E., Ramulu, S., Stiekema, W. J. \& de Groot, B. 1989. Fate of introduced genetic markers in transformed root clones and regenerated plants of monohaploid and diploid potato genotypes. Theor. Appl. Genet., 78, 185-193.

Welkie, G. W. 1993. Iron stress responses of a chlorosis-susceptible and chlorosis-resistant cultivars of pepper (Capsicum annuum L.). In Optimization of Plant Nutrition (Fragoso, M. A. C. \& van Beusichem, M. L., eds.), pp. 483-489. Kluwer Academic Publishers, Netherlands.

Welkie, G. W. 1996. Iron-deficiency stress responses of a chlorosis-susceptible and chlorosisresistant cultivar of muskmelon as related to root riboflavin excretion. J. Plant Nutr., 19, 1157-1189.

Zambryski, P., Tempé, J. \& Schell, J. 1989. Transfer and function of T-DNA genes from Agrobacterium Ti and Ri plasmids in plants. Cell, 56, 193-201.

Zehra, M., Banerjee, S., Naqvi, A. A. \& Kumar, S. 1998. Variation in the growth and alkaloid production capability of the hairy roots of Hyoscyamus albus, H. muticus and their somatic hybrid. Plant Sci., 136, 93-99.

Yamamoto, O. \& Kamura, K. 1997. Production of saikosaponin in cultured roots of Bupleurum falcatum L. Plant Tissue Cult. Biotechnol., 3, 138-147.

\title{
Tropaanalkaloidide süntees Hyoscyamus niger L. karvjuurekloonides ja riboflaviini eraldumine söötmesse
}

\author{
Rael Vardja, Katrin Pudersell, Tõnis Vardja, Ain Raal ja Elmar Arak
}

On uuritud võrdlevalt Hyoscyamus niger L. hariliku (WT) juure ja Agrobacterium rhizogenes LBA 9402 abil saadud transgeensete karvjuurekloonide tropaanalkaloidide sünteesi juurtes ja riboflaviini eraldumist söötmesse. Väljavalitud kuuest karvjuurekloonist oli üks kloon (C-1) morfoloogiliste tunnuste ja kasvu intensiivsuse poolest sarnane WT juurtega. Ülejäänud, kiiresti kasvavad (FG) karvjuurekloonid kasvasid kaks korda kiiremini kui WT juured ja olid neist morfoloogiliselt erinevad. Karvjuurekloon C-1 sünteesis olenevalt söötmest (MS, B5, Knop-M) 5 kuni 15 korda rohkem skopolamiini ja 1,5 kuni 2 korda rohkem hüostsüamiini kui WT juured. FG karvjuurekloonid sünteesisid enamikus vähem tropaanalkaloide kui WT juured, kuid nende süntees olenes suurel määral söötme koostisest. Riboflaviini eraldumine karvjuurekloonist C-1 oli mõnevõrra väiksem kui WT juurtest. FG karvjuurekloonidest eralduva riboflaviini hulk jäi minimaalse määramispiiri lähedale, kuid selle eraldumine söötmesse suurenes tunduvalt raua defitsiidi korral. 